\title{
Contextualisation of Factual Knowledge in Genetics: A Pre- and Post- Survey of Undergraduates' Understanding of the Nature of Science
}

\author{
Imme Petersen ${ }^{1}$, Stephanie Herzog ${ }^{2}$, Corinna Bath ${ }^{1}$, André Fleißner ${ }^{2}$
}

\author{
${ }^{1}$ Institute of Flight Guidance, Technische Universität Braunschweig, GERMANY \\ ${ }^{2}$ Institute of Genetics, Technische Universität Braunschweig, GERMANY \\ *Corresponding Author: i.petersen@tu-braunschweig.de
}

Citation: Petersen, I., Herzog, S., Bath, C., \& Fleißner, A. (2020). Contextualisation of factual knowledge in genetics: A pre- and post- survey of undergraduates' understanding of the nature of science. Interdisciplinary Journal of Environmental and Science Education, 16(2), e2215. https://doi. org/ 10.29333/ijese/7816

\section{ARTICLE INFO}

Received: 10 December 2019

Accepted:

17 February 2020

\section{ABSTRACT}

Having an adequate understanding of the Nature of Science (NOS) is an integral part of scientific literacy. However, NOS is usually not yet explicitly embedded in the science curricula at German universities. To fill this gap, we have introduced NOS elements in the undergraduate course on genetics at the biology department of an Institute of Technology in North-western Germany in summer semester 2018. The strategy used an exclusive-reflective approach by emphasising socio-scientific issues. As Kostas Kampourakis (2016) suggests, our design considers not only general aspects of the NOS concept, but also the family resemblance approach presented by Erduran and Dagher (2014). To evaluate changes in students' NOS understanding, we did a pre- and post-survey about their NOS understanding following the SUSSI questionnaire designed by Liang et al. (2008). The NOS understanding of the 93 participants shows statistically significant improvement in 14 out of 24 items (58,3\%) after the teaching unit, compared to the pre-survey. While the pre-survey shows a larger gap of understanding regarding the relations of environment, theory, and law, the post-test results show significant effects on learning, in particular regarding subjective, social, and cultural influences on science. However, the students' understanding regarding the relations of environment, theory, and law still remains weak. The findings indicate that some preconceptions were not as amenable to change as others. In particular, the assumed facticity of scientific knowledge seems to be a powerful preconception that is much more firmly fixed than the contextualization of scientific discovery.

Keywords: scientific literacy, undergraduates, genetics, nature of science, NOS, family resemblance approach, biology, biotechnology, Germany

\section{INTRODUCTION}

The overall goal of science education in school and university is to enhance scientific literacy (e.g. Bybee \& McCrae, 2011; Laugksch, 2000; McComas, 2017). Even if the term represents a complex idea, it basically implies knowledge of the content and methods of science, as well as of the nature of science (e.g. Abd-El-Khalick, Bell \& Lederman, 1998; Kirchner, 2010). Accordingly, students need to acquire both factual knowledge on laws, concepts, models, and theories in science, as well as experimental techniques and procedures and reflexive knowledge on epistemological understandings, values, and beliefs inherent in scientific knowledge and its development (Lederman, 2006; N. G. Lederman \& Lederman, 2014;
Schulz, 2014). Hence, being scientifically literate means being able to understand how scientists work and how scientific knowledge is processed for making informed decisions on personal and societal issues. This becomes more and more important in the era of 'post-truth', in which increasing information is available but its sources are becoming increasingly complex and incomprehensible (e.g. Rose, 2018).

To understand the characteristics of science and the significance and relatedness of science in society, it is frequently claimed that students need to develop an understanding of the nature of science (NOS) from primary school onwards (e.g. Akerson \& Ad-El-Khalick, 2005; Khishfe, 2008; Tao, 2003). Even though there is on-going 
debate among science education researchers about the concept of NOS and its age-adapted implementation, there is a general consensus about the most relevant elements of NOS that should be included in science curricula (McComas \& Olson, 1998; Lederman, Abd-El-Khalick, Bell \& Schwartz, 2002; Niaz, 2009; Osborne, Collins, Ratcliffe, Millar \& Duschl, 2003). Accordingly, an appropriate NOS understanding is characterized by the notion that scientific knowledge involves a combination of both empirical evidence (observations of the natural world) and subjective behaviour (scientists' backgrounds, experiences and biases). Furthermore, NOS understanding sees scientific knowledge as durable, yet tentative. It may be modified or altogether changed under the influence of new information; it is the product of human creativity and imagination, and is socially and culturally embedded. A sound understanding of the NOS should also include an ability to distinguish between observation (data) and inference (result), as well as theory and law as different components of the structure of knowledge (Abd-El-Khalick \& Lederman, 2000; Lederman, Abd-El-Khalick, Bell \& Schwartz, 2002; Lederman, 2006, 2007). Taken these characteristics together, NOS understanding refers to the epistemological underpinnings of the activity and products of science and not simply to science processes (Lederman, Antink, \& Bartos, 2014).

Consequently, NOS has been incorporated in multiple standard documents on science education worldwide (McComas \& Olson, 1998; AAAS, 2007; OECD, 2017). While teaching NOS has a long tradition in English-speaking countries and more recently in Asian countries, in Germany it is only implemented in directives for school teaching (Sekretariat der Ständigen Konferenz der Kultusminister der Länder der Bundesrepublik Deutschlands, 2005a, 2005b, 2005c). These national science education standards aim at contributing to scientific literacy, including NOS as one of four areas of competency (Neumann, Kauertz \& Fischer, 2010). However, national science education standards for university education are not yet available in Germany.

Most empirical research on NOS views has focused on primary and secondary school teachers and their students, in order to understand how ideas about science are taught and learned in school. These studies have found that neither teachers nor students typically hold informed views of NOS (e.g. Lederman, Lederman, Bartels \& Jimenez, 2019; Michel \& Neumann, 2017; Dogan \& AbdEl-Khalick, 2008, Kang, Scharmann \& Noh, 2005; Khishfe \& Abd-El-Khalick, 2002).

However, the NOS understanding of university students has received comparatively little attention. The majority of existing studies have focused on those who are studying to become teachers, as they will communicate the NOS to the next generation. Empirical results demonstrate that college students enrolled in a history of science course held naive or inaccurate ideas about NOS, similar to those of high school students (Abd-El-Khalick, 2006; Ibrahim, Buffler \& Kubben, 2009). Some studies compared NOS views of natural science and non-natural science majors, finding no significant differences (Liu \& Tsai, 2008; Desaulniers Miller, Montplaisir, Offendahl, Cheng \& Ketterling, 2010). A few studies that have examined the NOS ideas of undergraduate science majors in the U.S. have stressed that the students' views were mainly influenced by the idea of ,truth' in science. The surveyed students stated, for example, that all claims in science can be proved or disproved empirically (Ryder \& Leach, 1999). In addition, Dagher and BouJaoude (1997) have shown that undergraduate biology majors held very narrow definitions of what a scientific theory is. This permits them to dismiss many of the theories used in biology as being unscientific. Comparably, Parker and her colleagues (2008) have argued that according to students in atmospheric science, scientific theories and laws are related by a hierarchy of proof, where a theory is unproven, and once proven, becomes a law.

Such empirical results indicate that students often hold preconceptions that form the basis for an incorrect perception of various aspects of NOS, such as that science gives definitive answers or that scientists are always objective. Therefore, teaching about NOS involves a process of change from existing preconceptions, whose construction often starts in elementary school and that become more and more implicit and resistant later on (e.g. AbdEl-Khalick \& Lederman, 2000; Clough, 2006; Chen, Chang, Lieu, Kao, Huang \& Lin, 2013). Hence, it is important to address students' preconceptions about NOS before and after NOS teaching interventions at different age levels - which includes science education beyond primary and secondary school.

A deeper understanding of how such naive NOS views of students in the early stages of their bachelor programme can be changed is still pending. Nevertheless, it is important to study this group of university students because natural science students will later on have careers in science and will be communicating science to the public and political decision-makers in both formal and informal settings (Kampourakis, 2016). We experience undergraduate students in the life sciences following contemporary debates on fake news and post-truth and raising questions regarding meaning, responsibility, and the applicability of science and technology. However, at least in the German context, they often feel overwhelmed or left alone with this pressing issue, as reflections of the 
knowledge production and on its social context are usually not embedded in the curricula yet. To face this development, we started an innovative programme in undergraduate teaching at a biology department at a university in North-western Germany in the summer semester of 2018. We chose the course 'basics of genetics' as it is a compulsory course in the beginning of the bachelor programmes 'biology' and 'biotechnology'. Within both curricula, the course is valued as important to introduce into the basics of the vital subfield of genetics, as well as to introduce into the self-understanding of the life sciences.

Within the existing curricula, we designed a NOS teaching unit that explores historical and current cases in genetics from the NOS perspective (see Abd-El-Khalick, 2013). We supplemented the lecture with extra workshops using cooperative learning and small-group discussion tools (see Wolfensberger \& Canella, 2015). The workshops allowed the students to reflect the NOS approach. As Kostas Kampourakis (2016) suggests, our design considers not only the domain-general aspects of the NOS concept, but also the "family resemblance“ approach, presented by Erduran and Dagher (2014), to enhance students' capacity for perceiving scientific knowledge in its epistemological and socio-scientific context.

The study reported here intends to assess the newly designed NOS teaching unit in terms of its effects on students' views on selected aspects of NOS understanding. The study is therefore split into two parts: First, we investigate the NOS understanding of bachelor students enrolled in an undergraduate biology course on genetics before the course has started; based on the students' initial NOS views, we explore changes in their NOS understanding after teaching the newly designed NOS teaching unit. This approach aims at answering the following research questions: (1) What are the preconceptions on various NOS aspects of science students enrolled in a bachelor course on genetics? (2) In what ways, if any, do these preconceptions change through the newly designed teaching unit?

\section{Teaching Genetics with a NOS Understanding}

Research on teaching approaches that intend to enhance an understanding of NOS demonstrates that students do not automatically learn about NOS when they are engaged in inquiry activities and, following from that, do not automatically learn about NOS by doing science (e.g. Schwartz \& Crawford, 2006; Khishfe \& AbdEl-Khalick, 2002). Instead of teaching NOS understanding implicitly, Abd-El-Khalick and Lederman (2000) argue that NOS understanding needs to be explicitly addressed in the science curricula. They suggest an explicit-reflective approach, whereat the instructional sequence of the teaching unit should include specific NOS learning outcomes to improve students' NOS understanding. It is recommended that the students investigate the NOS concept by learning about the content of science (Khishfe \& Abd-El-Khalick, 2002; Abd-El-Khalick \& Lederman, 2000). Furthermore, the teaching unit should support students' awareness of NOS aspects through enhancing student reflection on their science learning experiences (Abd-El-Khalick, 2013). Addressing students' ability to reflect about the NOS concept seems to be necessary, as students often hold incorrect perceptions and believes in myths about science, such as that science gives definite answers, or that scientists' work is always objective and value-free (Lederman, 1992; McComas, 1998).

For addressing such incorrect perceptions about NOS, Kampourakis (2016, p. 669) values the domain-general NOS aspects as an effective entry point (e.g. Lederman, 2007; McComas, 1998; Niaz, 2009; Osborne et al., 2003). Once this is done, it seems promising to supplement NOS teaching with aspects specific to the disciplinary context to which the NOS teaching refers to.

The use of domain-specific content in the form of science stories - cases from the history of science - has been an often-chosen approach in teaching about NOS (Teixeira, Greca \& Freire, 2012; Howe \& Rudge, 2005; Howe, 2007; Kim \& Irving, 2010) and has had a long tradition in science teaching (Matthews, 2012). Several studies report the positive effects of instructional units that incorporate historical case studies into teaching about NOS. After these teaching interventions, students' understanding of several NOS aspects showed an improvement (Irwin, 2000; Lin \& Chen, 2002; Rudge \& Howe, 2009; Paraskevopoulou \& Koliopoulos, 2011; Wolfshagen \& Canella, 2015). However, McDonald (2017) shows in her analysis of Australian junior secondary textbooks representations of NOS within the topic of genetics that NOS was not sufficiently explicitly addressed in the case studies. She particularly criticizes missing links and guiding questions to represent the interconnection of the different NOS aspects towards a more holistic NOS understanding (see also Campanile et al., 2015 for the example of NOS representations in the Mendelian genetics sections of U.S. high school biology textbooks). Against the backdrop of genetics, she further concludes that not all NOS aspects have to be necessarily included to represent the holistic NOS understanding within the chosen context. Hence, NOS aspects may be differently represented depending on the science disciplines or the science topics within disciplines.

Metz and his colleagues (2007) argue that science stories need to meet some requirements in order to be suitable for domain-specific teaching about NOS such as in genetics. They are supposed to illustrate the course 
of scientific inquiry, and, at the same time, several, if not all relevant domain-general NOS aspects. Different narratives about each historical case should be available (e.g. technological, biographical, political, social, ethical etc.) and be condensed to storylines with protagonists, incidents, and plots that connect the incidents. Erduran and Dagher (2014) utilized these complex science stories to develop a classification that can be used to detect domain-specific NOS aspects that are relevant to a particular science story under study. The classification is based on the idea of family resemblance, in particular to the fact that the members of a family can resemble one another in some details but not in others (Irzik \& Nola, 2014). Based on resemblances and differences within the science system, Erduran and Dagher (2014) state that all scientific disciplines share certain characteristics; however, none of these characteristics define science or specifies certain disciplines. To introduce this family resemblance approach (FRA) visually, they developed the family resemblance approach wheel that identifies science as a cognitive-epistemic and a social-institutional system at the same time. Both systems are subdivided into a number of categories that are not necessarily equally important in each science story (see Figure 1). Science as a cognitive-epistemic system refers to scientific aims and values, scientific knowledge, scientific practices, as well as scientific methods and methodological rules. These four categories are embedded into a larger concentric circle encompassing professional activities, scientific ethos, social certification and dissemination, and social values.
Finally, a meta-level characterization of three categories related to science in society are part of an outer circle: financial system, social organizations and interactions, and political power structure. The boundaries between the circles and the categories included in them are interwoven, perforated, and allowing fluid movement across lines (Erduran \& Dagher, 2014).

For teaching domain-specific NOS, the FRA wheel enables a differentiated picture of science. While FRA highlights both the similarities and the differences among scientific disciplines, it provides a coherent approach to capture domain-general and domain-specific aspects of NOS at the same time (McDonald, 2017).

Taken for granted that science is an interactive and dynamic endeavour, the FRA wheel allows choices for selecting the NOS content that is most relevant to the science story under study, e.g. by looking closely at epistemic or institutional categories or focusing on relations between categories. Therefore, this domain-specific approach can be used to permeate overarching science stories in specific scientific fields and disciplines based on the articulation of the various aspects of NOS (Erduran, Dagher, \& McDonald 2019), while at the same time domain-general aspects, associated with the general NOS consensus view, are represented in the FRA wheel as well.

\section{The NOS Teaching Unit}

We designed a NOS teaching unit for the undergraduate course 'basics in genetics' that combines the domain-general and domain-specific approaches in a

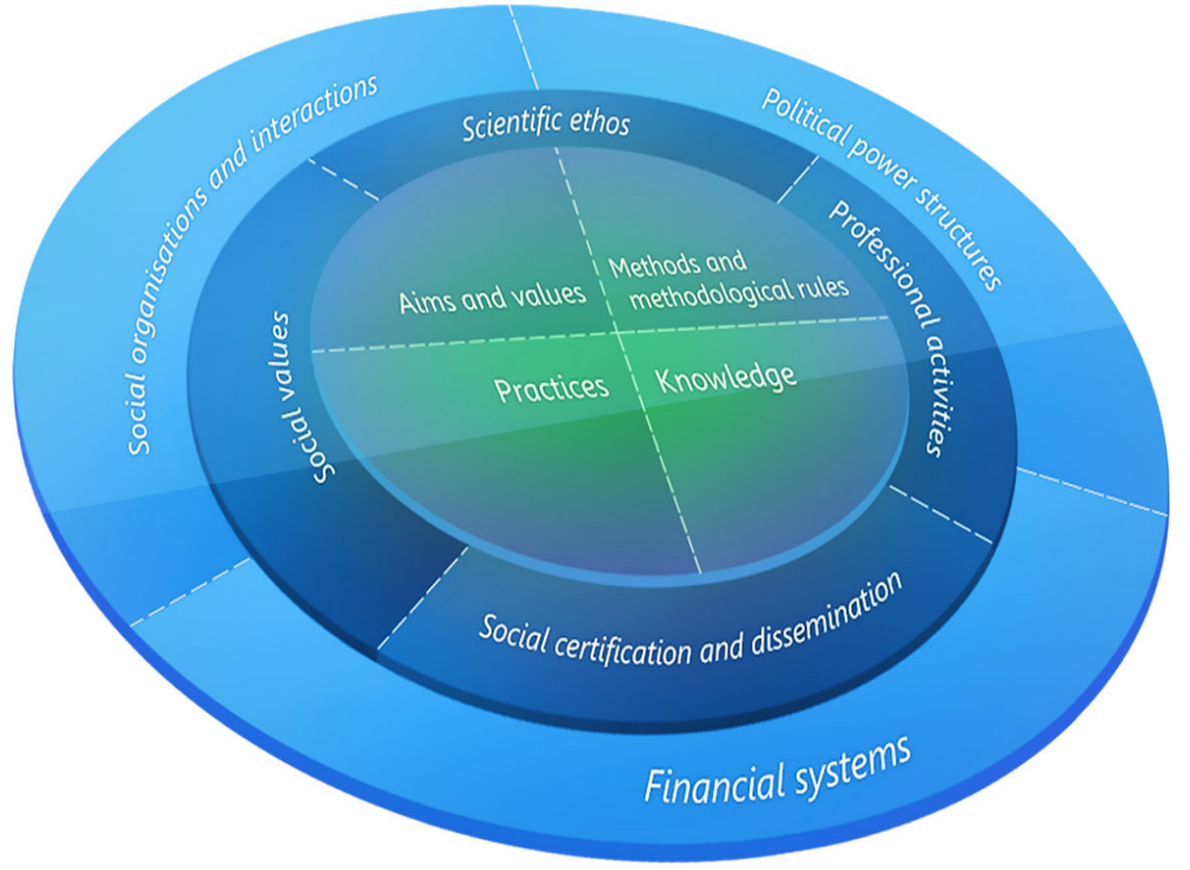

Figure 1. FRA Wheel: Representing science as a cognitive-epistemic, social-institutional and political system (reprinted with permission from Erduran and Dagher (2014, p. 28) 
learning pathway. The NOS unit was integrated in an existing introductory genetics class for second semester biology and biotechnology students. The compulsory class teaches the foundations of classical and molecular genetics, including the laws of inheritance, the molecular basis of genetics and general experimental concepts of genetic research in bacteria and higher organisms. The course consists of two parts, lecture and tutorial. During the lecture, given as teacher-centred teaching for about 100 students, the basics of genetics have been introduced by the process of scientific inquiries to produce genetic knowledge, which were key to the development of modern genetics. Recurrent parts of the historical science stories are the protagonists (usually the acting scientist(s)), the objects of study (e.g. organisms like Drosophila melanogaster, Streptococcus spe. or Escherichia coli), the methodology used (e.g. experiments, modelling) and the scientific knowledge produced (for example the laws of heredity or the description of genes, chromosomes, DNA structure, or mutations). Before introducing the NOS unit into the course, the previous presentation focussed mostly on the scientific facts and the experimental concepts leading to their discoveries. While the main historic protagonists were briefly introduced, no sufficient contextualization was provided. It became obvious that as a consequence, the students failed to develop an NOS understanding and often viewed scientific facts as independent of the process and the protagonists of their discovery. The previous teaching concept of presenting the science content in form of historical science stories was, however, very well suited to start teaching NOS concepts explicitly.

The specific learning outcome of the NOS teaching unit for the students was defined as developing NOS perceptions associated with scientific literacy. Lederman and his colleagues (Lederman, Antink, \& Bartos, 2014, p. 292) demonstrate in their paper that socio-scientific issues offer a vivid context for students to reflect on NOS perceptions, in particular regarding the nature of scientific knowledge and its interpretation in a given socio-cultural context. Therefore, we selected socio-scientific issues arising from genetics intending to enhance basic (domain-general) NOS perceptions associated with scientific literacy. However, our aim was not to teach students individual NOS aspects, but to present NOS holistically in a contextualised manner. That is why we first introduced NOS as an academic concept and talked about why it is important to include NOS explicitly in the curricula. In the lecture, we continued with an overview of domain-general aspects of NOS understanding by elaborating on the issue of how science produces epistemic knowledge within the science system and discussing what kind of socio-scientific issues might come up during knowledge generation in terms of societal interests, effects, and consequences (Sadler, 2004). By this stage of the lecture, we started to elaborate explicitly on domain-specific NOS aspects in genetics. The introduction of the FRA wheel helped us to highlight the political and societal dimensions in conjunction with social-institutional and cognitive-epistemic issues. On the one hand, we introduced the FRA wheel as a pedagogical tool that provides a set of categories to identify a variety of shared and distinct features that characterize the sciences. As the domain-general aspects are included in the FRA categories, we addressed in which FRA category they take effect, e.g. the notion of tentativeness of knowledge in the FRA-category "scientific knowledge", the notion of empirical evidence in the category "scientific methods and methodological rules", the notion of the scientists' subjectivity in "scientific ethos" or the notion of social and cultural embeddedness in the meta-level categories „financial system, social organisations and interactions, and political power structure". At the same time, the FRA wheel provides a framework that allows to highlight particular NOS aspects that are most relevant to the science stories in genetics (Erduran, Dagher \& McDonald, 2019).

We exemplified the entanglement of domain-specific and domain-general application on the basis of two popular historical inquiries in the field of genetics, namely the laws of heredity by Gregor Mendel and the model of the DNA structure by James Watson, Francis Crick and Rosalind Franklin. The cases were presented by different materials, e.g. through narrative texts and the protagonists' own words, photographs and charts. Afterwards, the given materials were structured and discussed by applying the FRA wheel. In this process, the particularly relevant NOS aspects for the stories were explicitly stressed.

For example, in the case of the Mendelian genetics we first presented the well-known story told in the science textbooks. Afterwards we re-structured the science story by the FRA wheel categories and highlighted in the discussion that the cognitive-epistemic system dimensions such as the produced scientific knowledge or the used methods and methodological rules are well considered in the textbook release, while social-institutional system dimensions such as Mendel's professional activities or the impact of social values or social organisations and interactions were only poorly or unbalanced addressed describing the monk Gregor Mendel as lonely and finally forgotten genius breeding peas isolated in the monastery garden (e.g. De Castro, 2016). For another example how to apply the FRA wheel see the science story on the DNA discovery in Dagher \& Erduran (2016, p. 157, Table 1). Meanwhile, there is some literature how the FRA framework can be linked to broader societal concepts such as 
social justice providing recommendations for curricula policy (Erduran, Kaya, \& Avraamidou, in press).

In order to engage students in reflexive discourses on NOS aspects (see also Wolfensberger \& Canella, 2015; Lederman, 2006), we complemented the lecture with a tutorial in which the students were invited to independently analyse historical, and later on, current science stories in genetics. We offered three parallel tutorials to keep the number of participants lower than 30; tutorial participation was voluntary. In the first tutorial session, we went over the FRA wheel with its categories again and gave the students guidelines for investigating FRA categories in science stories (see Kaya \& Erduran, 2016, p. 1124f.; Erduran, Kaya \& Dagher, 2018). The students read either Mendel's original paper (1866) or that of Watson and Crick (1953) and were invited to small-group work to select and discuss FRA categories that are relevant in terms of the content and style of the original paper. This small-group work was followed by a whole-class discussion that aimed at discussing the groups' selection of FRA categories in the two science stories. Finally, they were asked to draw conclusions about the progression of scientific endeavours and the development of genetics and science as a system. During the second tutorial session, the students were invited to use the acquired tools in the current controversy on the development of new genome editing tools, in particular CRISPR/Cas9. In recent years, a debate has raged over the merits of this technology, which culminated in patent disputes between the different institutes involved. The students were asked to prepare one section of discourse in independent group work for which they received selected publications (scientific reviews, reactions in science blogs, statements on the scientific certification system, scientific policy advice statements, media coverage on ethical issues and scientists' biographies). The student groups presented the prepared material in the tutorial session and expanded on selected NOS aspects in group discussions. Their task was to develop central questions for a plenary discussion to evaluate the research on genome editing regarding socio-scientific issues. Finally, they discussed their questions, e.g. should the Nobel prize in 2019 be granted for genome editing and, if yes, to whom?, in the plenary to synthesize the results.

\section{Pre- and Post- Evaluation of the Students' NOS Understanding}

The purpose of this research was not only to design a NOS teaching unit in genetics, but also to evaluate it by exploring the domain-general NOS understanding of the participants before and after the unit. In order to gain insight into students' views of NOS and their likely transition to genetics, we did a pre-test in the first and a post-test in the last lecture of the teaching unit, four weeks later.

\section{Survey}

As we wanted to assess changes or continuities in students' NOS perceptions over time, we decided to use the same instrument in pre- and post-testing. We employed a standardized questionnaire for large-scale research following the SUSSI questionnaire (Liang, Chen, Chen, Kaya, Adams, Nacklin \& Ebenezer, 2008).

The questionnaire used consists of 24 statements targeting six domain-general NOS themes: (1) observation and interferences, (2) change of scientific theories, (3) scientific laws versus theories, (4) social and cultural influence on science, (5) imagination and creativity in scientific investigation; and (6) methodology in scientific investigation. Each theme consists of four statements, each of which the survey participant has to evaluate by a five-point Likert scales ranging from strongly agree to strongly disagree.

The questionnaire was translated into German by the authors. The German version's clarity and comprehensibility was validated by two master's students at the biology department. The questionnaire was designed to be self-explanatory, stating the purpose and frame of the study and giving additional information, especially that participation is voluntary, that the analysis of the responses is carried out anonymously and in the aggregate only, and that there is no right or wrong answer to any of the questions.

\section{Data Analysis}

The responses of the participants to the Likert scale items were separately coded with numerical values and transcribed into a data matrix. A score of 5 represents the most informed NOS understanding and a score of 1 the least informed understanding. The positive scores 'strongly agree' and 'agree more than disagree' and the negative scores ,strongly disagree' and ,disagree more than agree' were pooled and presented together. For both, the pre- and the post-test, the mean scores for each Likert item were calculated and the effects of socio-demographic characteristics, type of major (biology, biotechnology), and NOS prior understanding were analysed. The preand post-survey were compared using the Pearson $\mathrm{c}^{2}$ test (2-tailored). $\mathrm{P}$ values for these analyses were considered significant if below the .05 level. Descriptive statistical procedures were performed using SPSS 25.0.

\section{Survey Participants}

100 students participated in the class, of which 93 voluntarily filled out the pre- and post-questionnaire. This corresponds to a return rate of $93 \%$. The 
socio-demographic characteristics are based on self-declaration by the students who filled out the questionnaire. The proportions of study programmes are almost balanced (biology 52,7\% and biotechnology 47,3\%). Nearly $80 \%$ of students are registered in their second semester. Two thirds of the participants are female (64,5\%). In the pre-test, about one third has heard of NOS in school or university before $(32,3 \%)$.

\section{Survey Results}

The pre-survey shows high uncertainty in the students' responses. The attenuated Likert-point ,agree more than disagree' consistently reaches higher scores than the ensured Likert-points, strongly agree' and 'strongly disagree' with three exceptions. Therefore, we only assume high certainty in the students' NOS perceptions from the outset in those three cases. Uncertainty is also reflected in the point ,neither agree nor disagree' that reaches more than $25 \%$ in 15 Likert items of the questionnaire, in one item even reaching $45,2 \%$.

The post-survey mirrors an increasing certainty in the responses (see Figure 2). Compared to the pre-survey, the amplitude of the categorical Likert-points ,strongly agree' and respectively ,strongly disagree' is considerably higher in all Likert items. However, the vague Likert-point ,neither agree nor disagree' still reaches in some of the items more than $30 \%$.

Subgroups of the survey (study programme, semester, gender, prior NOS knowledge) are statistically not relevant in the pre- and post-survey.

\section{NOS Themes}

Observations and inferences: The pre-survey participants assess scientific observations as a process affected by subjective influences. $82,8 \%$ of the students confirm that the scientists' prior knowledge may affect their observations. Objectivity is considered achievable only for about $12 \%$ of the participants, whereas $54,8 \%$ of them state that objective observations are not be possible. Accordingly, more than half of students regard observations as distinct from facts.

Compared to the pre-survey, the post-survey consistently show higher scores and more secure responses. Items on subjectivity and objectivity in research are statistically relevant: $93,5 \%$ of respondents confirm the influence of researchers' subjectivity on their scientific work, of which $51,6 \%$ were very secure (pre-test: $22,6 \%$ ) and only $5,4 \%$ are insecure about their answer $(p<0,001)$. The other significant result questions researchers' objectivity: $88,1 \%$ of the post-participants reject the statement that scientists' observations of the same event will be the same, because scientists are objective, and only 2,2\% are convinced that objectivity is possible in observation $(p<0,001)$.

Change of scientific theories: Two-thirds of all pre-survey students state that scientific theories are preliminary and constantly under review $(73,1 \%)$. Nearly all students accept that scientific theories can be rejected and replaced because of new knowledge. This item receives the highest score of secure responses in the entire questionnaire ('strongly agree', 65,6\%; together with 'agree more than disagree', 99,1\%). The majority also accept that existing observations can be re-interpreted, resulting in theory change $(80,7 \%)$. However, asked for the relevance of experiments on the stability of theories, about twothirds of students separate experiment from observation and acknowledge accurate experiments as unchangeable facts contributing to the resistance of theories to change

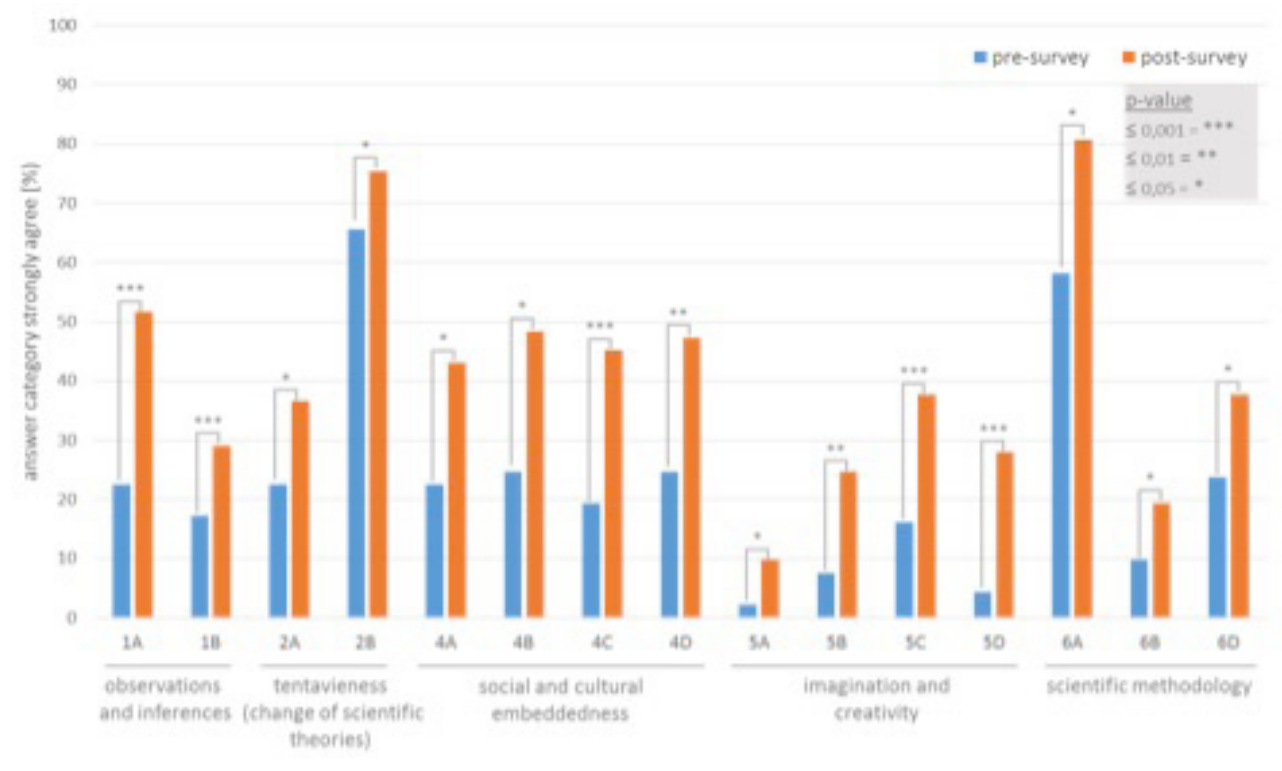

Figure 2. Overview of statistically relevant increases within the answer category ,strongly agree or disagree respectively 
$(62,3 \%)$.

The post-survey shows more secure results than in the pre-test in every statement. For example, $75,3 \%$ of participants strongly agree that scientific theories can be replaced $(p=0,034)$ and also the increase on the statement that theories are constantly under review is statistically significant $(p=0,047)$. Here the categorical answer is $14 \%$ higher than in the pre-survey. Thus, the results reflect coherence in the responses, indicating that the students have gained a profound understanding of the provisional nature of theories.

Scientific laws vs. theories: In this section the weakest results are obtained, which indicates the biggest misunderstandings regarding NOS. The section begins with the positivist position that scientific theories exist in the natural world and are investigated by scientifically exact methods. Only $14 \%$ reject this statement, whereas $47,3 \%$ confirm it. $47,3 \%$ also acknowledge that scientific laws are - in contrast to theories - not subject to change. The majority of the students doesn't seem to understand the relation of theories and laws: $57 \%$ assume that laws are permanently proven theories and $60,2 \%$ are of the opinion that theories would explain scientific laws.

Compared to the pre-survey results, the post-survey again shows consistently higher scores in terms of NOS understanding. However, taking into consideration that only a few participants in pre-testing give answers that correspond to NOS, the post-scores are also highly below the questionnaire average and there are no statistically relevant increases. However, a notable increase can be seen in the item where $22,6 \%$ reject the claim that scientific theories exist in the natural world and are uncovered by scientific investigation. On the contrary, slightly more students than in the pre-survey claim that scientific laws are proven theories (58\%). From this it follows that, for the majority of students, the relation of theory and law remains diffuse and unclear even after the NOS teaching unit.

Social and cultural influence on science: On average, 60 to $70 \%$ of pre-survey participants agree that culture and society influence scientific research. The statements that cultural values and expectations determine what science is $(73,1 \%)$ and how science is conducted are the most approved (65,6\%). These results go hand-in-hand with the statement of about two thirds of the students who question the impartiality of scientists $(62,4 \%)$ and the independence or universality of science $(69,6 \%)$.

Compared to the pre-survey, NOS understanding increases in a statistically relevant manner in all four statements of the post-survey $(p=0.04,0.011,0.004$, $<0.001$ ). The NOS-corresponding scores reach more than $80 \%$ in three of four items. In sum, these results indicate the significant learning effects of the NOS teaching unit, reflecting increased sensitivity regarding the cultural and societal framework conditions of research and science.

Imagination and creativity in scientific investigation: In the view of the pre-survey participants, data collection is a non-creative process; only $28 \%$ claim that scientists need creativity and imagination for data collection. Instead, $51,6 \%$ of students acknowledge that data analysis and interpretation need creativity, whereas the majority doesn't value creativity in conflict with logical reasoning $(62,3 \%)$. Some participants run into trouble when they are asked to assess creativity in comparison to objectivity: $45,2 \%$ hold the opinion that they wouldn't affect one another. It can therefore be concluded that objectivity in research processes is valued as relevant, but this value is seen as susceptible to risk.

As in the previous section, there is a statistically relevant increase in all four statements of the post-survey $(p=0.02,0.005,0.001,<0.001)$. The NOS corresponding responses are about $20 \%$ higher compared to the pre-survey. These results indicate the high learning effects of the NOS teaching unit. However, NOS understanding is not homogenous spread in this section, as about half of the post-survey respondents evaluate data collection as a creative process $(46,3 \%)$, while $73,1 \%$ agree the statement that data analysis and interpretation need creativity and imagination. About $80 \%$ see a relationship between creativity and logical reasoning, too $(80,6 \%)$. The learning effect in the evaluation of objectivity seems to be high: $68,9 \%$ of the students claim that imagination and creativity don't interfere with objectivity (increase of 23,7\%).

Methodology of scientific investigation: The variety of methods is recognized by nearly all pre-survey participants $(92,5 \%)$ and about $60 \%$ are highly convinced of their evaluation ('strongly agree', 58,1\%). This corresponds to the approval of the statement that experiments are not the only means used to generate scientific knowledge $(65,6 \%)$. However, there are still uncertainties regarding the evaluation of methods: Nearly half of the participants state that scientists need to follow the same step-by-step scientific method $(48,4 \%)$, whereas $40,9 \%$ doubt that the correct use of method would always produce accurate and true results.

As in the two previous sections, the increase in the NOS-corresponding responses is statistically relevant in three out of four statements of the post-survey $(p=0.017$, $0.042,0.02$ ). Again, the scores indicate more security in NOS perceptions compared to the pre-survey, for example an increase of $22,5 \%$ in the first item and $13,9 \%$ in the last. However, half of the participants remain uncertain about the relation of method and result, as only about half of the participants $(48,4 \%)$ disagree with the statement that the 
correct application of the scientific method would always lead to accurate and true results.

\section{DISCUSSION}

Up until now, very few studies have evaluated NOS teaching units for undergraduate students with specific majors. We designed a NOS teaching unit for a compulsory course in the basics of genetics being attended by undergraduates of the bachelor programme of 'biology' and 'biotechnology' at a German university.

As we observed that our students in the life sciences often feel disoriented in public controversy on genetics in the era of fake news and post-truth, the specific learning outcome of the NOS teaching unit was defined as developing NOS perceptions associated with scientific literacy. For this purpose, we chose socio-scientific issues arising from genetics to utilize them as a context for students to enhance scientific literacy through reflections on NOS in a context-sensitive manner (Lederman, Antink, \& Bartos, 2014). The socio-scientific emphasis in the teaching material made it necessary to provide a broader perspective including domain-general and domain-specific NOS aspects. In the FRA, we found a systematic approach to expand the general consensus view to domain-specific NOS aspects. We used FRA as a framing tool to embed domain-general NOS aspects into the socio-scientific context (Erduran \& Dagher, 2014; Dagher \& Erduran, 2016); Correspondingly, we emphasised the entanglement of domain-general notions claimed by the general consensus view with the FRA categories to exemplify the interconnections of the different representations of NOS aspects (McDonald, 2017). In addition, we used the FRA wheel as a visualization tool to structure science stories in a holistic and contextualized manner (see also Erduran, 2017).

In students' tutorial work, we made in particular positive experiences with the FRA wheel (Erduran \& Dagher, 2014). The self-regulated learning exercises showed that the wheel categories were easy to understand and easy to deploy to science stories relevant to highly conflictual socio-scientific issues such as the scientific battle of detecting the DNA structure or, more recently, the modification of the DNA by gene editing tools.

From our perspective, the presented NOS teaching unit utilising socio-scientific issues as a context for enhancing student reflection on basic (domain-general) NOS understanding associated with scientific literacy was suitable. The explicit NOS instruction during the lecture opened the students' minds towards a first understanding of the epistemology of science, while the application of the FRA wheel embedded genetics in its socio-scientific frame and finally provided a more complete picture of different and interdependent contexts being affected by science.
However, we wanted to evaluate the impact of the newly-designed teaching unit by applying a standardized procedure to investigate students' initial NOS understanding (before the NOS teaching unit started) and right after it was finished. We chose the established and tested SUSSI questionnaire (Liang et al., 2008) that represents all the relevant domain-general NOS perceptions that are - according to the general consensus - supposed to be included in science curricula (e.g. Osborne, Collins, Ratcliffe, Millar \& Duschl, 2003). The intent here was to assess the newly designed learning pathway that aims at enhancing domain-general NOS perspectives by focussing on socio-scientific issues in genetics. We assumed that the students' NOS understanding would benefit from the introduction of the FRA as a frame for analysing general-specific NOS aspects against the backdrop of their context-sensitiveness. However, it was not a focus of our survey to evaluate or score the impact of FRA on the consensus perspective, as we focused on the evaluation of the domain-general NOS aspects.

The results of the pre-survey demonstrate more basic NOS understanding than previously expected. Prior NOS knowledge may contribute to that, as $32 \%$ of the survey participants indicate that they have heard of NOS in school or university before. However, the difference in this group's performance is not statistically significant in any single item, compared to the students who don't report having prior NOS knowledge. Hence, prior NOS experiences don't seem to have any effect on the students' preconceptions.

Despite the uncertainty concerning clarity of denomination, the pre-survey shows in detail that the participants hold different perceptions regarding elements of the general-domain NOS concept. In particular, the statements referring to the change of scientific theories reach secure responses (up to 99\%). NOS corresponding responses regarding social and cultural influences on science are also notable. Here, scores are very homogeneous with an average of 60 to $70 \%$. For example, the statement that cultural values and expectations determine what science is has the highest approval (73\%).

However, a clear gap of understanding appears in the item section on theories versus laws: The relationship of environment, law, and theory in genetics seems not to be understood in terms of the production of scientific knowledge. This misunderstanding goes together with the contradictory results on subjective influencing factors, where less than the half of the participants explicitly reject the statement that scientists would not use their imagination and creativity because these can interfere with objectivity.

Taken together, the results of the pre-survey suggest 
that correct and incorrect perceptions of the core elements of the consensus on NOS concept can co-exist in the minds of the students. Even though positivism and objectivity seem to be at the core of students' scientific self-understanding, what science is (and how it is performed) is accepted by the majority as culturally and socially driven.

Our conclusions regarding the NOS understanding of German science students enrolled in a bachelor course on genetics confirm conclusions of the few studies that have examined the NOS ideas of undergraduate science majors in the U.S. Using the SUSSI questionnaire, Desaulniers Miller and her colleagues (Desaulniers Miller, Montplaisir, Offerdahl, Cheng, \& Ketterling, 2010), for example, found relatively informed views of scientific theory and relatively uninformed views of the distinction between scientific theories and laws among biology majors (see also Liu \& Tsai, 2008). Our results also correspond to previous study results concluding that natural science majors recognize the authority of objectivity and proof in creating valid, sustained, and hence, true knowledge (Ryder \& Leach, 1999; Dagher \& BouJaoude, 1997; Parker, Krockover, Lasher-Trapp \& Eichinger, 2008). Accordingly, when scientific knowledge is out in the world, the surveyed students in our and other survey(s) believe that it exists independently of scientific discovery.

The post-survey conducted with the identical SUSSI questionnaire with Likert scale items four weeks after the pre-survey demonstrates high learning effects on the students' NOS understanding. Compared to the pre-survey, the number of answers displaying NOS understanding increase up to $20 \%$ throughout the questionnaire. Statistically significant are responses showing the increase in NOS understanding in 14 out of 24 items. In total, these represent $58,3 \%$ of the items allocated throughout sections $1,2,4,5$, and 6 . The students have, therefore, internalised the contextualization of science and research. The Likert scores in particular suggest that research is recognized as a process that permanently takes place under subjective, social, and cultural influences.

This result is contrary to two studies investigating the NOS views of undergraduate majors in math and physics, where the students especially struggled with the subjective, social, and cultural dimensions more than others (Shi \& Wang, 2017; Hanuscin, Akerson \& PhillipsonMower, 2006). In particular, Shi and Wang (2017) make up a societal-driven argument: Chinese students struggle with the paradox of whether science is objective or subjective, because the predominance of Marxist dialectical materialism favours a belief in the material world and in science's objectivity in discovering it.

In our study, in contrast, the comparison between pre- and post-testing demonstrates that scientific aims and values in terms of objectivity as the authority of natural science research is increasingly at stake after the NOS teaching unit. So, nearly $90 \%$ of the post-test participants reject the statement that scientists are objective in terms of making the same observations; nearly $80 \%$ reject the statement that scientists are not influenced by society and culture because they are trained to conduct pure, unbiased studies; and nearly $70 \%$ of the students reject the statement that scientists do not use their imagination and creativity because these can interfere with objectivity.

Compared to the aims and values of scientific research, the post-test participants still have more difficulties in acknowledging the contextualization of scientifically achieved knowledge in the form of data, theories, and laws. Even though these items altogether show increase compared to pre-test results, the section of scientific theory change, and therefore of the provisional nature of theory, does not notably profit from the NOS teaching unit. The results regarding the relation of environment, theory, and law shows some, but weak and not statistically relevant, increase. Maybe this uncertainty reflects the students' wish for scientific knowledge, detached from the contextualized research process, to retain its facticity. This desire corresponds with the increasing uncertainty of assessing currently available 'post factual' information on socio-scientific issues in genetics.

\section{CONCLUDING REMARKS}

The evaluation of the undergraduate NOS teaching unit reveals that the newly designed learning pathway was able to reach incorrect or weak preconceptions regarding NOS understanding associated with scientific literacy. We assume that the exclusive-reflective approach chosen has the potential to inform a NOS understanding that also communicate the complexity of socio-scientific issues in today's post-truth era. The statistically significant increase in 58,3\% of the items reflect striking changes in the students' perceptions of various elements of the domain-general NOS conception. However, the detailed analysis of the results has shown that some preconceptions are not as amenable to change as others. In particular, the assumed facticity of scientific knowledge seems to be a powerful preconception that is much more fixed than the contextualization of scientific discovery. This might suggest that powerful preconceptions are more resistant because they correspond with the scientific self-understanding. Hence, they are more deeply internalised and more implicit than others (e.g. Chen et al., 2013). However, more research on the internalization and learning processes of NOS knowledge is necessary to shape NOS teaching correspondingly. 
This study gives an example of an exclusive-reflective teaching approach emphasising the socio-scientific frame that may be transferable to other biology and biotechnology majors in the beginning of their bachelor studies. Finally, we want to emphasise that this study took place at a German university. Up until now, empirical data have mainly originated from the American and Asian university context with long NOS teaching traditions at university. By comparison, German universities are an interesting field of study as no national science education standards for university education are available yet. Hence, teaching and researching on students NOS perceptions at German university have different presuppositions than in the countries previously in focus.

\section{ACKNOWLEDGEMENTS}

We thank the students for participating in the NOS teaching unit and the surveys as well as the teach4TU team at the Universität Braunschweig for their excellent support, in particular Lisa Dornieden, Susanne Sandau, Katharina Zickwolf and Ute Zaepernick-Rothe.

\section{Disclosure Statement}

No potential conflict of interest was reported by the authors.

\section{REFERENCES}

Abd-El-Khalick, F. (2006). Over and over again: college students' views of nature of science. In L.B. Flick \& N. G. Lederman (Eds.), Scientific Inquiry and Nature of Science: Implications for Teaching, Learning, and Teacher Education (pp. 389-426). Dordrecht, The Netherlands: Kluwer Academic Publishers.

Abd-El-Khalick, F. (2013). Teaching with and about nature of science, and science teacher knowledge domains. Science \& Education, 22(9), 2087-2107.

Abd-El-Khalick, F., Bell, R. L., \& Lederman, N. G. (1998). The nature of science and instructional practice: Making the unnatural natural. Science Education, 82(4), 417-436.

Abd-El-Khalick, F., \& Lederman, N. G., (2000). Improving science teachers' conceptions of the nature of science: A critical review of the literature. International Journal of Science Education, 22, 665-701.

Akerson, V. L., \& Abd-El-Khalick, F. S. (2005). "How should I know what scientists do?-I am just a kid": Fourth-grade students' conceptions of nature of science. Journal of Elementary Science Education, 17(1), 1-11.

American Association for the Advancement of Science (AAAS). (2007). Atlas of science literacy. Vol. 2. New York: Oxford University Press.

Bybee, R. W., \& McCrae, B. J. (2011). Scientific literacy and student attitudes: Perspectives from PISA 2006 Science, International Journal of Science Education, 33(1), 7-26.

Chen, S., Chang, W.-H., Lieu, S.-C., Kao, H.-L., Huang, M.-T., \&Lin, S.-F. (2013). Development of an empirically based questionnaire to investigate young students' ideas about nature of science. Journal of Research in Science Teaching, 50(4). 408430.

Clough, M. P. (2006). Learners' responses to the demands of conceptual change: Considerations for effective nature of science instruction. Science \& Education, 15(5), 463-494.

Campanile, M. F., Lederman, N. G. \& Kampourakis, K. (2015). Mendelian genetics as a platform for teaching about nature of science and scientific inquiry. Science \& Education, 24, 205-225.

Dagher, Z. R., \& BouJaoude, S. (1997). Scientific views and religious beliefs of college students: The case of biological evolution. Journal of Research in Science Teaching, 34, 429-445.

Dagher, Z. R., \& Erduran, S. (2016). Reconceptualizing the Nature of Science for Science Education: Why Does it Matter?. Journal of Research in Science Teaching, 25, 147-164.

De Castro, M. (2016). Johann Gregor Mendel: Paragon of experimental science. Molecular Genetics and Genomics Medicine, 4(1), 3-8. https://doi.org/10.1002/mgg3.199

Desaulniers Miller, M. C., Montplaisir, L. M., Offerdahl, E. G., Cheng, F.-C., \& Ketterling, G. L. (2010). Comparison of views of the nature of science between natural science and nonscience majors. CBE-Life Sciences Education, 9, 45-54.

Dogan, N., \& Abd-El-Khalick, F. (2008). Turkish grade 10 students' and science teachers' conceptions of nature of science: A national study. Journal of Research in Science Teaching, 45(10), 1083-1112.

Erduran S. (2017). Visualizing the nature of science: Beyond textual pieces to holistic images in science education. In $\mathrm{K}$. Hahl, K. Juuti, J. Lampiselkä, A. Uitto \& J. Lavonen (eds), Cognitive and Affective Aspects in Science Education Research. Contributions from Science Education Research, vol 3. (pp. 15-30). Dordrecht: Springer. https://doi.org/10.1007/978-3319-58685-4_2

Erduran, S., \& Dagher, Z. (2014). Reconceptualizing the nature of science for science education: Scientific knowledge, practices and other family categories. Dordrecht: Springer.

Erduran, S., Dagher, Z.R. \& McDonald, C.V. (2019). Contributions of the family resemblance approach to nature of science in science education. Science \& Education 28, 311-328, https:// doi.org/10.1007/s11191-019-00052-2

Erduran, S., Kaya, E., \& Dagher, Z. (2018). From lists in pieces to coherent wholes: Nature of science, scientific practices, and science teacher education. In J. Yeo, T. W. Teo \& K. S. Tang (Eds.), Research and Practice in the Asia-Pacific Region (pp.324), Dordrecht: Springer.

Erduran, S., Kaya, E., \& Avraamidou, L. (in press). Does research on nature of science and social justice intersect? Exploring theoretical and practical convergence for science education. In H. Yacoubian \& L. Hansson (Eds.), Nature of Science for Social Justice. Dordrecht: Springer.

Hanuscin, D. L., Akerson, V. L., \& Phillipson-Mower, T. (2006). Integrating nature of science instruction into a physical science content course for preservice elementary teachers: NOS views of teaching assistants. Science Education, 90(5), 912-935.

Howe, E. M. (2007). Addressing nature-of-science core tenets with the history of science: An example with sickle-cell anemia \& malaria. American Biology Teacher, 69 (8), 467-472.

Howe, E. M., \& Rudge, D. W. (2005). Recapitulating the history of sickle-cell anemia research: Improving students' NOS views 
explicitly and reflectively. Science \& Education, 14(3-5), 423441.

Ibrahim, B., Buffler, A., \& Lubben, F. (2009). Profiles of freshman physics students' views on the nature of science. Journal of Research in Science Teaching, 46, 248-264.

Irwin, A. R. (2000). Historical case studies: Teaching the nature of science in context. Science Education, 84(1), 5-26.

Irzik, G. \& Nola, R. (2014). New directions for nature of science research. In M. Matthews (Ed.), International handbook of research in history, philosophy and science teaching (9991021). Dordrecht: Springer.

Kang, S., Scharmann, L. C., \& Noh, T. (2005). Examining students' views on the nature of science: Results from Korean 6 th, 8th, and 10th graders. Science \& Education, 89(2), 314334.

Kaya, E. \& Erduran, S. (2016). From FRA to RFN, or how the family resemblance approach can be transformed for science curriculum analysis on nature of science. Science \& Education, 25(9), 1115-1133.

Kampourakis, K. (2016). The "general aspects" conceptualization as a pragmatic and effective means to introducing students to nature of science. Journal of Research in Science Teaching, 53(5), 667-682.

Khishfe, R. (2008). The development of seventh graders' views of nature of science. Journal of Research in Science Teaching, 45(4), 470-496.

Khishfe, R., \& Abd-El-Khalick, F. (2002). Influence of explicit and reflective versus implicit inquiry oriented instruction on sixth graders' views of nature of science. Journal of Research in Science Teaching, 39, 551-578.

Kim, S. Y., \& Irving, K. E. (2010). History of science as an instructional context: Student learning in genetics and nature of science. Science \& Education, 19(2), 187-215.

Laugksch, R. (2000). Scientific literacy: A conceptual overview. Science Education, 84(1), 71-94.

Lederman, N. G. (1992). Students' and teachers' conceptions of the nature of science: A review of the research. Journal of Research in Science Teaching, 29(4), 331-359.

Lederman, N. G. (2006). Syntax of nature of science within inquiry and science instruction. In L. B. Flick, \& N. G. Lederman (Eds.), Scientific inquiry and nature of science. Implications for teaching, learning, and teacher education (pp. 301-318). Dordrecht: Springer.

Lederman, N. G. (2007). Nature of science: Past, present, and future. In S. K. Abell, \& N. G. Lederman (Eds.), Handbook of research on science education (pp. 831-879). Mahwah, NJ/ London: Erlbaum.

Lederman, N. G., Abd-El-Khalick, F., Bell, R. L., \& Schwartz, R. S. (2002). Views of nature of science questionnaire (VNOS): Toward valid and meaningful assessment of learners' conceptions of nature of science. Journal of Research in Science Teaching, 39(6), 497-521.

Lederman, N. G., Antink, A. \& Bartos, S. (2014). Nature of science, scientific inquiry, and socio-scientific issues arising from genetics: A pathway to developing a scientifically literate citizenry. Science \& Education, 23, 285-302.

Lederman, N.G., Lederman, J. S. (2014). Research on teaching and learning of nature of science. In N.G. Lederman, \& S. K. Abell (Eds.). Handbook of research on science education (Vol. 2, pp. 600-620). New York: Routledge.
Lederman, J., Lederman, N., Bartels, S., Jimenez, J. (2019). An international collaborative investigation of beginning seventh grade students' understandings of scientific inquiry: Establishing a baseline. Journal of Research in Science Teaching, 2019, 1-30. https://doi.org/10.1002/tea.21512

Liang, L. L., Chen, S., Chen, X., Kaya, O. N., Adams, A. D., Macklin, M., \& Ebenezer, J. (2008). Assessing preservice elementary teachers' views on the nature of scientific knowledge: a dual-response instrument. Asia-Pacific Forum on Science Learning and Teaching, 9, 1-20.

Lin, H.-S., \& Chen, C.-C. (2002). Promoting preservice chemistry teachers' understanding about the nature of science through history. Journal of Research in Science Teaching, 39(9), 773-792.

Liu, S., \& Tsai, C. (2008). Differences in the scientific epistemological views of undergraduate students. International Journal of Science and Education, 30, 1055-1073.

Matthews, M. (2012). Changing the focus: From nature of science (NOS) to features of science (FOS). In M. S. Khine (Ed.), Advances in nature of science research (pp. 3-26). Dordrecht: Springer.

McComas, W. F. (1998). The principal elements of the nature of science: Dispelling the myths. In W. F. McComas (Ed.), The nature of science in science education: Rationales and strategies (pp. 41-52). Dordrecht, The Netherlands: Kluwer.

McComas, W. F. (2017). Understanding how science works: The nature of science as the foundation for science teaching and learning. School Science Review, 98(365), 71-76.

McComas, W. F., \& Olson, J. K. (1998). The nature of science in international science education standard documents. In W. F. McComas (Ed.), The nature of science in science education: Rationales and strategies (pp. 41-52). Dordrecht: Kluwer.

McDonald, C.V. (2017). Exploring representations of nature of science in australian junior secondary school science textbooks: A case study of genetics. In C. V. McDonald \& F. Abd-ElKhalick (eds.), Representations of nature of science in school science textbooks: A global perspective (pp. 98-117). London: Routledge. https://doi.org/10.4324/9781315650524-5

Mendel, G. (1866). Versuche über Pflanzen-Hybriden: Verhandlungen des Naturforschenden Vereines in Brunn [Experiments in Plant Hybridisation. Paper for the Brünn Natural History Society]. Retrieved from www.esp.org/foundations/ genetics/classical/gm-65-f.pdf

Metz, D., Klassen, S., McMillan, B., Clough, M., \& Olson, J. (2007). Building a foundation for the use of historical narratives. Science \& Education, 16(3-5), 313-334.

Michel, H., \& Neumann, I. (2017). Nature of science and science content learning: The relation between students' nature of science understanding and their learning about the concept of energy. Science \& Education, 25(9-10), 951-975.

Neumann, K., Kauertz, A., \& Fischer, H. E. (2010). From PISA to standards - the impact of large scale assessments on science education research in Germany. International Journal of Science and Mathematics Education, 8(3), 545-563.

Niaz, M. (2009). Critical appraisal of physical science as a human enterprise: Dynamics of scientific progress. Dordrecht, The Netherlands: Springer.

Organization for Economic and Co-operation and Development (OECD). (2017). PISA 2015 technical report. Paris: OECD Publishing. 
Osborne, J., Collins, S., Ratcliffe, M., Millar, R., \& Duschl, R. (2003). What "ideas-about-science" should be taught in school science?: A Delphi study of the expert community. Journal of Research in Science Teaching, 40(7), 692-720.

Paraskevopoulou, E., \& Koliopoulos, D. (2011). Teaching the nature of science through the Millikan-Ehrenhaft dispute. Science \& Education, 20(10), 943-960.

Parker, L. C., Krockover, G. H., Lasher-Trapp, S., \& Eichinger, D. C. (2008). Ideas about the nature of science held by undergraduate atmospheric science students. Bulletin of the American Meteorological Society, 89, 1681-1688.

Rose, D. (2018). Avoiding a post-truth world: Embracing post-normal conservation. Conservation and Society, 16(4), 518-524.

Rudge, D. W., \& Howe, E. M. (2009). An explicit and reflective approach to the use of history to promote understanding of the nature of science. Science \& Education, 18, 561-580.

Ryder, J., \& J. Leach (1999). University science students' experiences of investigative project work and their images of science. International Journal of Science and Education, 21, 945-956.

Sadler, T. D. (2004). Informal reasoning regarding socioscientific issues: A critical review of research. Journal of Research in Science Teaching, 41, 513-536.

Schulz, R. M. (2014). Philosophy of education and science education: a vital but underdeveloped relationship. In M.R. Matthews (Ed.), International handbook of research in history, philosophy and science teaching (pp. 1259-1316). Dordrecht: Springer.

Schwartz, R. S., \& Crawford, B. A. (2006). Authentic scientific inquiry as context for teaching nature of science: Identifying critical elements for success. In L. B. Flick, \& N. G. Lederman (Eds.), Scientific inquiry and nature of science. Implications for teaching, learning, and teacher education (pp. 331-356). Dordrecht: Springer.

Sekretariat der Ständigen Konferenz der Kultusminister der Länder der Bundesrepublik Deutschland [KMK]. (2005a). Bildungsstandards im Fach Biologie für den Mittleren Schulabschluss (Jahrgangsstufe 10). Neuwied: Luchterhand.

Sekretariat der Ständigen Konferenz der Kultusminister der Länder der Bundesrepublik Deutschland [KMK]. (2005b). Bildungsstandards im Fach Chemie für den Mittleren Schulabschluss (Jahrgangsstufe 10). Neuwied: Luchterhand.

Sekretariat der Ständigen Konferenz der Kultusminister der Länder der Bundesrepublik Deutschland [KMK]. (2005c). Bildungsstandards im Fach Physik für den Mittleren Schulabschluss (Jahrgangsstufe 10). Neuwied: Luchterhand.

Shi, W.-Z., \& Wang, J. (2017). Comparison on views of nature of science between math and physics students. Journal of Baltic Science Education, 16(1), 77-85.

Tao, P. K. (2003). Eliciting and developing junior secondary students' understanding of the nature of science through a peer collaboration instruction in science stories. International Journal of Science Education, 25(2), 147-171.

Teixeira, E. S., Greca, I. M., \& Freire, O. (2012). The history and philosophy of science in physics teaching: A research synthesis of didactic interventions. Science \& Education, 21, 771796.

Watson, J. D., Crick, F. H. (1953). Molecular structure of nucleic acids; a structure for deoxyribose nucleic acid. Nature, 171,
737-738.

Wolfensberger, B., \& Canella, C. (2015). Cooperative learning about nature of science with a case from the history of science. International Journal of Environmental and Science Education, 10(6), 865-889. 